\title{
THE REALIZATION OF SPEECH FUNCTION IN ONANG - ONANG: HOW AND WHY?
}

\author{
Linda Efrina Nasution \\ English Department \\ Sekolah Tinggi Keguruan dan Ilmu Pendidikan (STKIP) Padang Lawas \\ l.efrina@yahoo.com
}

\begin{abstract}
The main objectives of this study are to investigate the realization of Speech Function in Onang - onang and the reason for their realization. This study is based on descriptive qualitative approach. The data are collected by applying documentary technique. The result of this study reveales that the process of realization of Speech Function in Onang - onang in Mood is realized both congruent and metaphorically. The reasons for realization of Speech Function in Onang- onang are power initiation, Politeness need and also there are different language systems and grammatical structures between North Padang Lawas language and English clause structure.
\end{abstract}

Keywords: Speech Function, Mood, Onang-onang.

\section{INTRODUCTION}

Language achieves its goal through three kinds of metafunctions. Metafunctions is general functions of language in social contexts: to enact relationships, to represent the experience, and to organize discourse as meaningful text. The systemic functional linguistic studies recognize three kinds of metafunctions: ideational, textual and interpersonal metafunctions.

Halliday and Matthiessen (2014: 30) state that sometimes language is used to enact our personal and social relationship with the other people around us, this function of language is called interpersonal metafunction. It means interpersonal metafunctions shows us the speakers attitudes toward their relationship in personal and social interactions with the listener.

According to Halliday (2002: 189), "language itself defines the roles which people may take in situations in which they are communicating with one another; and every language incorporates options whereby the speaker can vary his (or her) own communication role, making assertions, asking questions, giving orders, expressing doubts and so on". Saragih (2013:17) also states that speech function refers to a function performed by a speaker in a verbal interaction or conversation which specifies his or her role and the content or commodity transacted. When people interact with other person, we not only use language to exchange information, to argue about whether things are or are not. We also use language to influence each other's behaviour. Human interaction 
recognized two categories for using language to exchange goods and services; giving goods and services (which gave us the speech function offer), and demanding goods and services (which gave us the speech function command).

Table 1.Basic Speech Roles

\begin{tabular}{|l|l|l|}
\hline Role in exchange & Commodity \\
\hline Giving & Offer & Information \\
\hline Demanding & Command & Statement \\
\hline
\end{tabular}

(Thompson, 2013)

Table above shows that a statement is any stretch of language that functions to give information to the addressee; a question is any stretch that functions to elicit information from the addressee; a command is any stretch whose intended function is to influence the behaviour of the addressee in some way; and offer is any stretch whose function is to initiate or accompany the giving of goods- \&-services to the addressee.

In the semantic aspect the four speech functions find their realization in Mood. Halliday and Matthiesen (2014: 97) say Mood is the major interpersonal system of the clause; it provides interactants involved in dialogue with the resources for giving or demanding a commodity, either information or goods- $\&$-services - in other words, with the resources for enacting speech functions (speech acts) through the grammar of the clause: statements (giving information), questions (demanding information), offers (giving goodss- $\&$-services), and commands (demanding goods- $\&$-services).

Saragih (2013:21) says the unmarked realization of speech funtion also termed congruent or common realization or coding while the incongruent or uncommon realization of speech function is termed metaphorical coding or realization. In other word, the metaphorical coding is the uncommon realization of speech function based on the figure 2. This uncommon realization of speech function is called metaphorical realization. For instance, usually statement is realized in declarative mood, but the speaker used introgative mood in deliver their speech.

In interpersonal metafunction the choice of using metaphorical variant is related to the social distance, which is usually discussed in terms of status, formality and politeness. Metaphorical variants create a greater semiotic distance between meaning and wording, and this enacts a greater social distance between speaker and addressee. The semiotic 
distance is often manifested directly in the lexicogrammar as a syntagmatic extension of the wording. The combinations of tenor values relating to status and contact correlate with different semantic strategies open to speakers for demanding goods- $\&$-services of their listeners - for commanding their listeners. If the status is unequal, with the speaker being subordinate to the listener and the contact is minimal, the speaker's semantic options are very limited: it is very hard to command a stranger who is of superior status to do something; but there will be certain semantic strategies. The strategy that can be used is remove the congruent realization and using metaphor of command, for instance " $I$ wonder if you be so kind to.....". The speech of the clause above is command but realized in introgative, it means that clause is incongruent or metaphor.

In this research the theory of realization of Speech function is applied in Onang onang. Onang-onang is a cultural song that is usually sung by singer which is called "Paronang-onang". Onang-onang is usually sung to accompany a traditional dance named tor-tor. Onang- onang is divided into two kinds, firstly onang- onang is in the context of happiness (siriaon) and the second onang- onang is in the context of mourning (siluluton). The lyric of Onang- onang usually consist of advice, appraisal and wishes of the singer about the ceremony that being held. In the wedding ceremony the lyric of Onang- onang is sung spontaniously by Paronang- onang without written the lyrics. After getting the physical and mental description of groom (bayo pangoli) and the bride (boru nadioli), the song is created based on their life and social status.

Nowdays, besides in a wedding ceremony, Onang - onang is sung in national ceremony, escorting the national guest, and on the opening of national events. The lyrics of Onang - onang tells listener about the memory of the Tor - tor dancer, the singer tells the life story of the groom and bride, since they were baby until they got married. In North Padang Lawas wedding, a ceremony is held by control of three important pillars that known as "Dalihan Natolu". "Dalihan Natolu" is a community of North Padang Lawas cultural community in society which consist of Suhut and their Kahanggi, Mora and Anak Boru. Every ceremony in North Padang Lawas can not be separated from the influence of the Suhut and their Kahanggi, Mora and Anak Boru, includes in wedding ceremony and also funerals.

The Onang- onang also influenced by "Dalihan natolu", it can be seen from the kinds of Onang- onang songs itself. There are some kinds of Onang- onang songs, for instance: 
Onang- onang Suhut (parents of the groom), Onang- onang Mora (parents of the bride), Onang - onang Anak Boru (the sisters and brother in law of Suhut), Onang- onang Pisang Raut (nephew and niece of Suhut), Onang- onang Naposo Nauli Bulung (teenagers), and also Onang- onang Boru (groom and bride). The difference of the kinds of Onang- onang can be seen in the lyrics and the groups of Tor-tor dancer, because Onang-onang Suhut is sung only for Suhut when they are dancing Tor-tor, and Onang- onang Mora is sung only for Mora when they are dancing Tor-tor. The lyrics of Onang-onang describes about the relationship of one person with others. Onang- onang Suhut describes the relationships among the Suhut as the group of Tor-tor dancer, their names, their social status, their family lines, their loves and their hopes to the groom and bride and the family that held the ceremony.

Gerot and Wignell (1994:38) said that Mood in English is realised by the position in the clause of the Subject and Finite ( unmarked or congruent representation). Gerot and Wignell (1994:38) said that Mood in English is realised by the position in the clause of the Subject and Finite ( unmarked or congruent representation). The example of English clause analysis can be seen as follows:

\begin{tabular}{cccc} 
The driver & must & have been & very uncomfortable \\
\hline Subject & Finite & Predicator & Complemment \\
\hline Mood & & Residue \\
\hline
\end{tabular}

The clause above is a statement which is realized in declarative Mood. Declarative Mood is indicated by Subject followed by finite. This theory seem not suitable for North Padang Lawas language clause. North Padang Lawas language clause mostly start with verb (predicator) followed by subject and then complement. Based on the theory of Systemic functional linguistic the clause that start from verb (predicator) and then subject and finite create marked Mood and incongruent clause. The difference of Mood analysis in English clause and North Padang Lawas language clause can be seen in the following

\begin{tabular}{l|c|c|c|}
$\begin{array}{l}\text { Madilehen } \\
\text { (Given }\end{array}$ & \multicolumn{1}{c}{$\begin{array}{c}\text { Guru } \\
\text { teacher }\end{array}$} & \multicolumn{1}{c}{ buku book } & \multicolumn{1}{c}{$\begin{array}{c}i \\
\text { the) }\end{array}$} \\
\hline Predicator & Subject & Compl. & Finite \\
\hline Residu & \multicolumn{3}{|c|}{ Mood } \\
\hline
\end{tabular}

The structure of North Padang Lawas language clause creates marked Mood that create incongruent clause, which start from Residu and Mood, this Mood structure also 
occur in Onang- onang lyrics. Some examples of marked Mood in Onang- onang lyrics are presented as follows:

The lyrics of Onang- onang

Majongjongi ale da namora da pule $i$

\begin{tabular}{|c|c|c|c|}
\hline (Standing & has & bride & the) \\
\hline Predicator & Finite & Subject & Finite \\
\hline Residu & \multicolumn{3}{|c|}{ Mood } \\
\hline \multicolumn{4}{|c|}{ Najong jongile sian kala ngului } \\
\hline (Standing & \multicolumn{3}{|c|}{ from throne) } \\
\hline Predicator & \multicolumn{3}{|c|}{ Finite Circ. Adjunct } \\
\hline \multicolumn{4}{|c|}{\begin{tabular}{|l|l|} 
Residu & \\
\end{tabular}} \\
\hline $\begin{array}{l}\text { Madung } \\
\text { (Has }\end{array}$ & $\begin{array}{l}\text { jongjongan } \\
\text { standing }\end{array}$ & \multicolumn{2}{|c|}{$\begin{array}{l}\text { di galanggangon } \\
\text { in arena) }\end{array}$} \\
\hline Finite & Predicator & \multicolumn{2}{|c|}{ Circ. Adjunct } \\
\hline
\end{tabular}

The analysis of Mood above shows the difference between the English and North Padang Lawas clause structure. In English, Mood elements consist of Subject followed by Finite and then Residu, but in North Padang Lawas language clause, it can not be applied. North Padang Lawas language clause mostly start from verb (predicator) followed by subject and then complement. The lyrics of Onang- onang above are declarative form, but Gerot and Wignell (1994:38) said that kinds of Mood that realised by the features Finite + Subject belongs to interrogative Mood. Based on the sentences above, it shows that Halliday theory of SFL especially in speech function is not suitable for North Padang Lawas language. In order to get more information and data about that, the writer would like to conduct further research about the same topic.

\section{METHODOLOGY}

The research design of this study is descriptive qualitative by using case study approach in order to describe Speech function in Onang - onang. According to Bogdan and Biklen (1992: 30), a qualitative method has a natural setting as the direct source of data. The qualitative means to find out how theory works in different phenomenon whose data collected are in the words rather than number. This research is designed with single case system, where it was conducted only in Onang-onang. This research was conducted by applying a case study approach. Ary, Jacobs and Sorensen state that a case study focuses on a single unit to produce an in-depth description that is rich and holistic. The underlying question is "What are the characteristics of this particular entity, phenomenon, person, or setting?" Case studies typically include multiple sources of data collected over 
time. The data of this research were the utterances consisting of Speech Function clauses in Onang- onang. The lyric of the Onang-onang were separated in to Mood elements. The main source of data in this research is recording of North Padang Lawas wedding ceremony of TUH and DSA. There are seven song lyrics that the writer analyzed in this study, they are Onang- onang Suhut male, Onang- onang Suhut female, Onang- onang Mora, Onang- onang Anak Boru, Onang-onang Raja Panusunan Bulung, Onang-onang Naposo Nauli Bulung, and Onang-onang Bayo Pangoli and Boru nadioli.

The data of this research is coding in such a way, Saldana (2009:3) says that "a code in qualitative inquiry is most often a word or short phrase that symbolically assigns a summative, salient, essence capturing, and / or evocative attribute for a portion of language - based or visual data". Onang- onang Suhut male is coded by SFO. SM, Onang- onang Suhut female is coded by SFO. SF, Onang- onang Mora is coded by SFO.M, Onangonang Anak Boru is coded by SFO.AB, Onang-onang Raja Panusunan Bulung is coded by SFO.RPB, Onang- onang Naposo Nauli Bulung is coded by SFO.NNB and then Onang- onang Bayo Pangoli and Boru Nadioli is coded by SFO. BP. Each of datum was coding by the name of the Onang- onang and the number of the datum, such as the datum of Onang- onang Suhut male number one is coded by SFO.SM01.

The data of the study were collected by applying documentary technique, a method for collecting the data which is kept in the form of documentation. To collect the data, the researcher record the wedding ceremony of TUH and DSA. After that the data of this research were analyzed by using steps adapted from Miles, Huberman and Saldana (2014). The procedures of analysis data are data collection, data condensation, data display and verification dan conclusion drawing. In qualitative research the data must be auditable. Lincoln and Guba (1985:209) stated that trustworthiness of a research study is important to evaluating its worth. The aim of trustworthiness of a research study is important to support the argument that the quirt's finding are worth paying attention to Lincoln and Guba (1985:200). It can be achieved through checking the credibility, transferability, dependability, and conformability.

\section{FINDINGS AND DISCUSSION}

There were 96 clauses are selected as the of speech function in Onang - onang. In order to find out the realization of Speech function in Onang- onang, the writer should find 
out the kinds of Speech function in Onang- onang first. The data of Speech Function in each of Onang- onang are presented as below.

Table 2 : Kinds of Speech Function in Onang-onang

\begin{tabular}{|c|c|c|c|c|c|}
\hline \multirow{2}{*}{ No. } & \multirow{2}{*}{ Kinds of Onang- onang } & \multicolumn{4}{|c|}{ Speech Functions (\%) } \\
\hline & & Statement & Offer & Question & Command \\
\hline 1. & Onang-onang Suhut Male & $88.46 \%$ & $3.85 \%$ & $0 \%$ & $7.69 \%$ \\
\hline 2. & Onang- onang Suhut Female & $77.77 \%$ & $0 \%$ & $0 \%$ & $22.22 \%$ \\
\hline 3. & Onang- onang Mora & $57.14 \%$ & $0 \%$ & $0 \%$ & $42.85 \%$ \\
\hline 4. & Onang- onang Anak Boru & $63.63 \%$ & $0 \%$ & $0 \%$ & $36.37 \%$ \\
\hline 5. & $\begin{array}{l}\text { Onang- onang Raja } \\
\text { Panusunan Bulung }\end{array}$ & $80.00 \%$ & $0 \%$ & $0 \%$ & $20.00 \%$ \\
\hline 6. & $\begin{array}{l}\text { Onang-onang Naposo Nauli } \\
\text { Bulung }\end{array}$ & $42.85 \%$ & $0 \%$ & $0 \%$ & $57.14 \%$ \\
\hline 7. & Onang-onang Bayo Pangoli & $66.66 \%$ & $0 \%$ & $0 \%$ & $33.33 \%$ \\
\hline
\end{tabular}

From the table above, it is shown the speech function that mostly dominated by statement, the second is command and offer while question is not appear in Onang-onang songs. In Onang- onang Suhut Male $88.46 \%$ of data are statement, $3.85 \%$ of data are offer then $7.69 \%$ of data are command. In Onang- onang Suhut Female $77.77 \%$ of data are statement, while $22.22 \%$ of data are command, there is no offer and question in Onang- onang Suhut female. The third song Onang-onang Mora shows $57.14 \%$ of data are statement and $42.85 \%$ of data are command, we can not find offer and question in this data. Then, in Onang - onang Anak Boru the researcher found $63.63 \%$ of data are statement and the rest of data $36.37 \%$ are command. Onang- onang Raja Panusunan Bulung used $80 \%$ of Statement and $20 \%$ of data are command. The table above also shows that Onang - onang Naposo Bulung used $42.85 \%$ of its lyrics are statement and command 57.14\%. Then the last song Onang -onang Bayo Pangoli, uses $66.66 \%$ of statement and $33.33 \%$ of command, this data does not have offer and question either.

Speech Function found their realization in Mood. There are three kinds of Moods, namely declarative, imperative and introgative. Statement realize in the declarative Mood, Command realize in imperative mood then question realize in the introgative mood, Speech function of Offer does not has specific realization in Moods. The realization of Speech function in Onang-onang can be seen in the table 3:

Table 3 : The Realization of Speech Function in Moods

\begin{tabular}{llccc}
\hline No. & Kinds of Onang-onang & Declarative & $\begin{array}{c}\text { Moods (\%) } \\
\text { Imperative }\end{array}$ & Introgative \\
\hline 1. & Onang- onang Suhut Male & $96.15 \%$ & $3.85 \%$ & $0 \%$ \\
2. & Onang- onang Suhut Female & $88.88 \%$ & $11.11 \%$ & $0 \%$
\end{tabular}




\begin{tabular}{llccc} 
3. & Onang-onang Mora & $71.42 \%$ & $28.57 \%$ & $0 \%$ \\
4. & Onang-onang Anak Boru & $72.73 \%$ & $27.27 \%$ & $0 \%$ \\
5. & $\begin{array}{l}\text { Onang-onang Raja } \\
\text { Panusunan Bulung }\end{array}$ & $86.67 \%$ & $13.33 \%$ & $0 \%$ \\
6. & $\begin{array}{l}\text { Onang-onang Naposo Nauli } \\
\text { Bulung }\end{array}$ & $85.71 \%$ & $14.28 \%$ & $0 \%$ \\
7. & Onang-onang Bayo Pangoli & $75 \%$ & $25 \%$ & $0 \%$ \\
\hline
\end{tabular}

The Table 3 shows that the most dominant Mood in Onang-onang is declarative mood. In every kinds of Onang- onang, declarative mood is mostly appear as the realization of speech function, while imperative mood in the second place, and also there is no introgative mood in Onang-onang.

The data in Table 3 shows that the Mood that realized in Onang - onang are declarative and imperative, while interogative Mood does not exist in Onang - onang, related to the kinds of Speech Function in Onang - onang there is no question realized in Onang - onang, the reason of why introgative does not exist in Onang - onang are because there is no speech function question and there is no metaphorical realization of Speech function that realized in introgative mood.

If the data above are compared with the kinds of Speech function in Table 2, it shows that there are some difference of number between kinds of Speech Function and how they are realized in the Mood. For instance, in Onang - onang Suhut Male data are found $88.46 \%$ data are statement and $3.85 \%$ of data are offer, then $7.69 \%$ of data are command, but in the realization of Speech Function its found that $96.15 \%$ of data are declarative, then $3.85 \%$ of data are imperative. There is a deviation of number of Statement and and declarative Mood, in table of the realization of Speech function in Mood, there are enhancement of declarative mood. It means there are some of command and offer found their realization in declarative Mood. It can concluded that for Onang onang Suhut Male the Speech Function realized in the congruent and metaphorical realization.

After comparing and analyzing the data of table 1 and table 2, it can be concluded that the Speech function realized in congruent and metaphorical realization in Mood. The Speech function that realized metaphorically is command, it usually realize in imperative Mood but for each of Onang - onang, there are some data of Command that realized in declarative Mood which create metaphorical realization of Speech Function. 
After found the realization of speech function in Onang-onang, the next step is find the reason of realization of Speech Function in Onang- onang. Related to the context of situation in terms of tenor, the participant that being involved in Onang- onang is Paronang-onang as the speaker and Suhut, Mora, Anak Boru, groom and bride as the listener and the subject of the Onang-onang. The status between the speaker in this occasion is unequal. Paronang- onang has more power than others, because he has a power to instruct the Tor - tor dancer to do what he asked in the lyric of Onang-onang. Paronang- onang is the person who take the role in giving instruction in dancing Tor tor. The status of the listener as a group of Tor - tor dancers are equal. Groom's parents has a same status with his brother or sisters as the parents of the groom's too. Eventhough Paronang -onang has more power than the Tor - tor dancer, but sometimes the social status of the participant in the ceremony is higher than him. In that condition Paronang onang has to modify his speech role in order to achieve the politeness in his song.

Ideologically, the cultural rule in North Padang Lawas is arranged systematically. When addresing someone with their nickname, we can know that man/woman come from the wife or husband family. For instance, when a child in a family meet his uncle, the listener can differentiate the background of his uncle family whether uncle from his mother side or uncle from his father side. For instance, uncle from mother side is called "Tulang" while uncle from father side is called " $U d a$ ". This ideology also appear in Onang-onang Suhut Male, Suhut consist of father of the groom and his uncles. His uncles can be the siblings or the cousin of his father, and his father has same right with his brother or cousin as Suhut and also in raising the son. If the groom's father has passed away, his brother can take the responsibility in raising his brother's children. It makes the position of uncle in family is equal with our father. That is why in the Onang-onang there are some repitition of word "amatta" which is means our father to indicate that uncle also is called with "amatta". Another rule in North Padang Lawas cultural community, people have to used word "amatta" in asking information about someone father. The word "amatta" is used to express the politeness in communication. For instance if someone want to ask "what is your father job?", he should use "aha do karejo ni amatta" (what is our father's job) this form is polite in North Padang Lawas, the form of the question is impolite if the speaker asking by this sentence "aha do karejo ni ayahmu" (what is your father's job?), it is 
impolite because citizen in North Padang Lawas believe every one has father, and people should consider them in the same rank.

Similarly with father, mother took important role in North Padang Lawas, her position in the song is explained as daughter, wife and mother. As daughter she is called as sinuan bulu (daughter), as wife she is called as Namora (the precious one), while as mother she is called as Inatta soripada (our respectful mother).

The wife in North Padang Lawas is termed with "Namora" and followed by the name of their husband, such as the wife of Tongku Gorga is called "Namora ni Tongku Gorga", the girl who has getting married will get a new name which is related to the name of his husband, her original name which is gave by her parents is not used in the cultural activity. The marriage law is arranged in such a good way. The marriage is considered to be valid if all the cultural procession has been done, such as giving the dowry and do the solemnization of marriage.

In wedding ceremony in North Padang Lawas, Bayo pangoli (groom) and Boru Nadioli (bride) are the main intention of song, the song is created to remaind the wedding couples, their parents kindness in raising them. For North Padang Lawas cultural community the birth of son means of richness (hamoraon) because they adopt the patrilianialisme, where son is needed to continue the lineage. The family surename is gotten from the surename of father. North Padang Lawas citizen is known for their hardworking in order to fullfill their son need in learning, it can be seen from the lyric of Onang- onang "Inatta natahan marudan marlasniari i mamikirkon da hepeng balanjo i" (our mother can do anything to accomplish your needs, get through the rain or facing the blistering sun), so that their son can get a better future. The lyric of Onang-onang Bayo Pangoli tell us about the life story of the groom since he was born, attending elementery school, junior high school, senior high school, get a job and getting married. The lyric of this song also show the love and happiness of the parents toward the wedding couple, that is why their wedding ceremony is held as huge as possible that take much cost and time.

The Paronang-onang modify his speech role in singing Onang- onang, using North Padang Lawas Language pattern or Batakness language pattern in Onang-onang has it's own reason. Onang- onang is known as kinds of song which has purposed to appraise, pray and advice the listener of the song. the reason of the Paronang- onang, using the pattern is to make the listener understand the message that he wants to delive. Speech 
function in Onang- onang song realize in the way they are because of the power initiation, the politeness need and difference of language structure between English and North Padang Lawas Languge.

After having the finding it can be concluded that a. The process of realization of speech function in Onang- onang are realised in congruent and declarative Mood, the congruent realization of Spech Function can be seen from the Speech function Statement realized in declarative mood while for metaphorical realization is caused by the realization of Command in declarative Mood. The construction of structure of the clause in Onang onang adopts the North Padang Lawas language structure which usually begin from predicator first. Based on the SFL theory for Speech function Statement the Mood elements was seem incongruent, but for Speech function Command the Mood elements based on North Padang Lawas clause seem congruent. The context or the reason of the realization of speech function is influenced by the social determinant and ideology that exist in North Padang Lawas cultural community. Speech function in Onang-onang song realize in the way they are because of the power initiation, the politeness need and difference of language structure between English and North Padang Lawas Languge. The finding of this research confirm the theory of Systemic Functional Linguistic from Halliday "in communication the addressee and the addreser used different speech role based on the context and the situation that they faced in communication".

\section{REFERENCESS}

Bloor and Bloor. 2004. The Functional Analysis of English a Hallidayan Approach, (Second Edition). Great Britain: Arnold A.

Bogdan, R.C and S.K. Biklen. 1992. Qualitative Research for Education. An Introduction to Theory and Methods. Boston: Allyn and Bacon

Denzin and Lincoln. 1994. Handbook of Qualitative Research. Thousand Oaks: Sage Publication

Eggins, S, 2004. An Introduction to Systemic Functional Linguistic (Second Edition), London: Continuum

Fontaine, L. 2013. Analysing English Grammar a Systemic Functional Introduction, New York: Cambridge University Press.

Gerot, L and P. Wignell. 1994. Making Sense of Functional Grammar, Australia: Gerd Stabler 
Halliday, M.A.K and J.J. Webster. 2009. Continuum Companion to Systemic Functional Linguistics, New York: continuum Companion.

Halliday, M.A.K and C.M.I.M Matthiessen. 2004. An Introduction to Functional Grammar (Third Edition), Great Britain: Arnold A.

Halliday, M.A.K and C.M.I.M Matthiessen. 2014. An Introduction to Functional Grammar (fourth Edition), New York: Routledge

Halliday, M.A.K. 2002. Language structure and language function', in J. Webster, ed., On Grammar. London: Continuum.

Hutasuhut, F.M. 2015. Nukilan Budaya Etnik Batak Angkola Mandailing, Medan: Perpustakaan Kota Medan

Lincoln, Y. S. \& Guba, E. G. 1985. Naturalistic Inquiry. Newbury Park, California: Sage Publications.

Lubis, S. 1997. Adat Hangoluan Mandailing Tapanuli Selatan, Medan.

Martin, J.R and D. Rose. 2007. Working with Discourse Meaning Beyond the Clause, London: Continuum.

Miles, Huberman \& Saldana. 2014. Qualitative Data Analysis: A Method Source Book ${ }^{\text {rd }}{ }^{\text {d }}$ Ed). USA: SAGE Publication Inc.

Mustikawati and Sumarlan. 2017. Interpersonl Metafunction in Interactive Dialogue Mata Najwa Metro TV, Lingua Journal.

Pasaribu. Ben M. 2004. Pluralitas Musik Etnik: Batak- Toba, Mandailing, Melayu, Pakpak- Dairi, Angkola, Karo dan Simalungun, Medan: Pusat Dokumentasi dan Pengkajian Budaya Batak Universitas HKBP Nomensen.

Saragih. A. 2013. Discourse Analysis A Study on Discourse Based on the Systemic Functional Linguistic Theory, Medan: Unimed Press.

Sibarani. I. S and Siringo - ringo L. 2017. Realization of Speech Function in Shampoo's Slogan in Television Advertisement. International Journal of Linguistic, Macrothink Institute, Vol.9, No.3, pp. 36-47.

Saldana, Johnny. 2009. The Coding Manual for Qualitative Researchers, London: Sage Publications.

Thompson, G. 2013. Introducing Functional Grammar (Third Edition), New York: Routledge.

Wang, J. 2014. The Mood and Modality in the Bible; a Systemic Functional Perspective, Academy Publisher Finland. 